\title{
Zastosowanie próby implant do oceny spawalności stali
}

\section{Application of implant test for evaluation of weldability of steel}

\section{Streszczenie}

Praca dotyczy oceny spawalności stali o podwyższonej i wysokiej wytrzymałości w aspekcie eksperymentalnego określania skłonności do tworzenia pęknięć zimnych. W artykule opisano metodykę określania wrażliwości na pękanie próbą implant. Przedstawiono również proponowane w literaturze i autorskie sposoby opracowywania i przedstawiania wyników badań rozpatrywaną metodą i ich interpretacji.

Słowa kluczowe: spawalność stali; badania spawalności; próba implant
Abstract

The work concerns the evaluation of the weldability of high strength steels in terms of the experimental determination of the tendency to form cold cracks. The article describes the methodology for determining the sensitivity to cracking by implant test. Proposed in the literature and authors ways to preparation and presentation of research results from the considered method and their interpretation are presented.

Keywords: weldability of steel; weldability tests; implant test

\section{Wstęp}

Spawalność jest jednym z podstawowych zagadnień rozważanych od momentu podjęcia pierwszych prób spawania. Norma PN-M-69005:1984 definiuje to pojęcie jako: „przydatność metalu o danej wrażliwości na spajanie do utworzenia w określonych warunkach spajania złącza metalicznie ciągłego o wymaganej użyteczności". W literaturze sformułowano wiele podobnie brzmiących definicji spawalności $[1 \div 3]$. Z ich analizy wynika, że większość autorów podkreśla następujące aspekty procesu przygotowania, tworzenia i eksploatacji złączy spawanych: wrażliwość danego materiału na oddziaływanie spawalniczego cyklu cieplnego, wpływ procesu spawalniczego na możliwość uzyskania metalicznej ciągłości i odpowiednich dla danego zastosowania własności użytkowych. W wynikającym ze względów praktycznych uproszczeniu pojęcie to sprowadza się często do skłonności stali do tworzenia pęknięć technologicznych: gorących, zimnych, lamelarnych i wyżarzeniowych.

W przypadku spawania stali o podwyższonej i wysokiej wytrzymałości najpoważniejszym ograniczeniem spawalności jest pękanie zimne $[1,2]$. Jest to zjawisko występujące jako skutek jednoczesnego oddziaływania wodoru i naprężeń pozostających na kruchą strukturę SWC lub spoiny

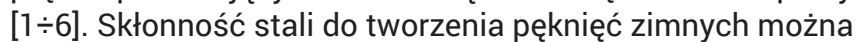
ocenić metodami eksperymentalnymi oraz opracowanymi na ich podstawie zależnościami analitycznymi, przy czym stosowanie tych drugich ogranicza się do wstępnego szacowania spawalności $[2,3,7,8]$.

\section{Eksperymentalne metody badań skłonności stali do tworzenia pęknięć zimnych}

Opracowano wiele metod badawczych służących ocenie zjawiska pękania zimnego $[2,7 \div 9]$. Próby temu służące powinny umożliwiać jednoczesne badanie wpływu czynników, które oddziałują na skłonność stali do tworzenia pęknięć, jak również swobodne zmiany wartości dowolnego z tych czynników. Metody badawcze stosowane do określania skłonności stali to tworzenia pęknięć zimnych można podzielić na trzy grupy $[2,7,8,10,11]$ :

- próby złączy utwierdzonych, w trakcie których utwierdzenie uzyskuje się poprzez wykonanie spoiny (spoin) lub poprzez zastosowanie sztywnego przyrządu mocującego elementy złącza,

- próby z regulowanymi naprężeniami przeprowadzane na próbkach spawanych obciążanych natychmiast po zakończeniu spawania siłami zewnętrznymi,

- próby na próbkach niespawanych stanowiące rodzaj eksperymentalnych symulacji polegających na imitowaniu warunków spawania i umożliwiających prowadzenie teoretycznej analizy mechanizmów odpowiadających za zjawisko pękania.

Eksperymentalne metody badań skłonności stali do tworzenia pęknięć na zimno można również podzielić na dwie zasadnicze grupy $[2,10]$ :

- próby jakościowe, których wynikiem jest stwierdzenie obecności albo braku pęknięć,

- próby ilościowe określające spawalność w postaci parametrów liczbowych wyrażonych w jednostkach.

Ponadto omawiane próby można sklasyfikować pod względem możliwości badania zjawiska pękania zimnego [6,7,12]:

- w SWC (np. implant),

- w spoinie (np. LB-TRC, G - BOP),

- w całym złączu (np. TRC, RRC, Tekken, CTS).

Szczegółowe badania mechanizmów tworzenia pęknięć zimnych podczas realizacji tych prób prowadzi się zarówno metodami niszczącymi (np. badania metalograficzne), jak i nienisz-

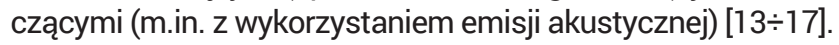

Dr inż. Dariusz Fydrych; dr inż. Grzegorz Rogalski; dr inż. Aleksandra Świerczyńska - Politechnika Gdańska.

Autor korespondencyjny/Corresponding author: darfydry@pg.gda.pl 
Do metod eksperymentalnych posiadających największe znaczenie praktyczne należy zaliczyć: próbę implant, Tek-

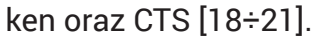

\section{Charakterystyka próby implant}

Idea badania skłonności stali do tworzenia pęknięć zimnych w SWC metodą implant została opracowana w 1964 r. we Francji przez zespół H. Granjona [22,23]. Od roku 1973, gdy próba implant została zarekomendowana przez MIS, zaczęto stosować ją w ośrodkach badawczych na całym świecie. Od tamtej pory ulegała modyfikacjom, których głównym celem było uproszczenie badań, zbliżenie warunków przeprowadzania eksperymentów do warunków występujących w rzeczywistych konstrukcjach, umożliwienie porównywania wyników z innymi metodami oceny skłonności do pękania opóźnionego oraz zapewnienie powtarzalności międzylaboratoryjnej $[9,12,24 \div 30]$. Podjęto również próby powiązania wyników uzyskiwanych z metody implant z zależnościami obowiązującymi w mechanice pękania [22], co ma na celu nadanie jej wynikom ścisłej interpretacji fizycznej. Prace te zaowocowały umieszczeniem próby implant w normach krajowych dotyczących badania skłonności stali do tworzenia pęknięć zimnych m. in. we Francji, Niemczech, krajach skandynawskich, Ukrainie, USA, Japonii, Chinach, a także w Polsce $[23,30 \div 36]$ i następnie w normie EN ISO [37].

Przeprowadzenie próby implant polega na wykonaniu spoiny próbnej na próbce (implancie), wykonanej z badanego materiału, umieszczonej w płycie pomocniczej (rys. 1). Podczas wykonywania spoiny zaleca się rejestrowanie cyklu cieplnego spawania z wykorzystaniem termoelementu, co ma na celu określenie czasów stygnięcia $t_{8 / 5}$ i $t_{3 / 1}$ [37]. Tak przygotowaną próbkę poddaje się obciążeniu na stanowisku badawczym, które stanowi maszyna wytrzymałościowa przystosowana do obciążania stałą siłą i pomiaru czasu eksperymentu [37]. Implanty (o średnicy 8 albo $6 \mathrm{~mm}$ ) wykonuje się obróbką skrawaniem w taki sposób, aby ich oś podłużna była równoległa do kierunku walcowania badanej blachy. Z jednej strony implantu nacina się gwint, który umożliwia zamocowanie go w stanowisku, a z drugiej wykonuje karb śrubowy albo cylindryczny (rys. 2). Zastosowanie karbu śrubowego zapewnia umiejscowienie go w SWC, co jest warunkiem koniecznym, niezależnie od zastosowanej metody i parametrów spawania. Poprawność narzucanej przez normę geometrii karbu należy sprawdzić, np. przy użyciu mikroskopu stereoskopowego. Wynik próby stanowi czas, po którym próbka ulega zerwaniu. W przypadku, gdy implant nie ulega zerwaniu w ciągu 16 h, próbę można przerwać [37]. W niektórych przypadkach zaleca się utrzymywanie obciążenia przez 24 h [18,27], a nawet 48 h [25]. Według zaleceń MIS [38] próbę należy przeprowadzać w ten sposób, aby badać trzy próbki w identycznych warunkach. Taki sposób przeprowadzania badań umożliwia eliminację błędów grubych i ocenę rozproszenia wyników pomiarów. Określenie skłonności SWC do tworzenia pęknięć zimnych odbywa się poprzez przeprowadzenie serii prób, co pozwala na wyznaczenie naprężeń krytycznych $\sigma_{\mathrm{kr}}$ - takich naprężeń, dla których co najmniej dwa implanty nie uległy zerwaniu w czasie $16 \mathrm{~h}$ [37]. Na rysunku 3 pokazano stanowisko „Implant 02" zbudowane na Politechnice Gdańskiej przez zespół pod kierunkiem dr inż. Tomasza Kozaka [36].

Ponieważ próba jest bardzo pracochłonna, w praktyce najbardziej efektywna jest następująca kolejność obciążania próbek [21]: rozpocząć należy od arbitralnie (zależnej od warunków przeprowadzania prób) wybranej wartości maksymalnej naprężeń $\mathrm{w}$ płaszczyźnie karbu $\sigma_{i}$, zmniejszając je stopniowo w kolejnych próbach aż do wartości, przy której implant nie ulegnie zerwaniu w ciągu znormalizowanego czasu (16 h). Następnie należy powtórzyć próbę dla tego samego obciążenia. Jeżeli kolejna próbka nie została zniszczona, to osiągnięty poziom naprężeń uznaje się za naprężenia krytyczne $z$ próby implant $-\sigma_{\mathrm{kr}}$. W przypadku przeciwnym należy przeprowadzać próby przy niższym obciążeniu aż do momentu, gdy dwie próbki nie ulegną zerwaniu w ciągu $16 \mathrm{~h}$. W dalszej kolejności należy wykonać próby dla wartości $\sigma_{\mathrm{i}}$ wyższych od $\sigma_{\mathrm{kr}}$.

O dokładności wyników badań decydują [31,36]: dokładność wykonania próbek implant (kołków) i otworów płyt pomocniczych, centryczne osadzenie implantu w otworze oraz osiowe jego obciążenie. Niepewność pomiaru metody

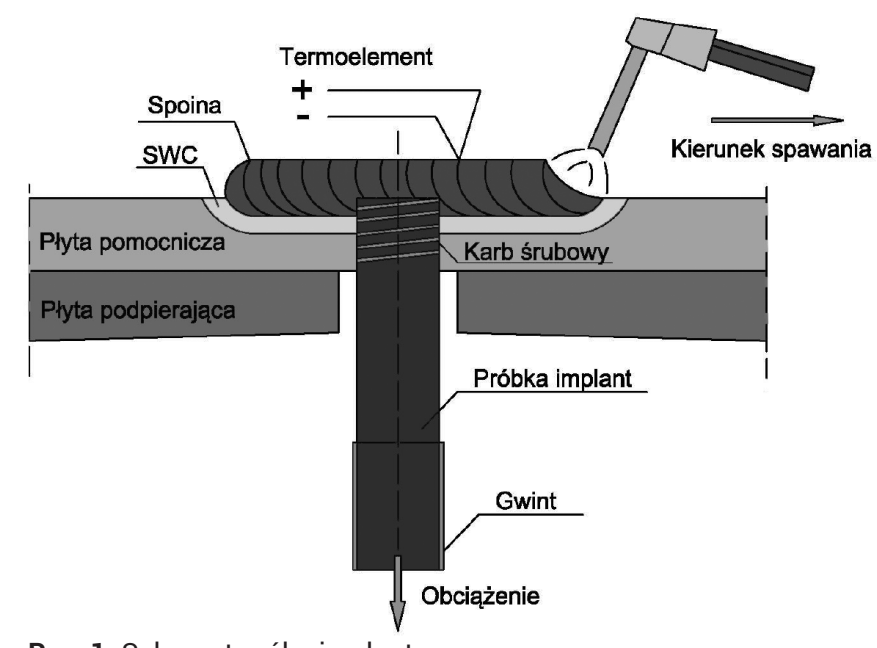

Rys. 1. Schemat próby implant

Fig. 1. Scheme of implant test

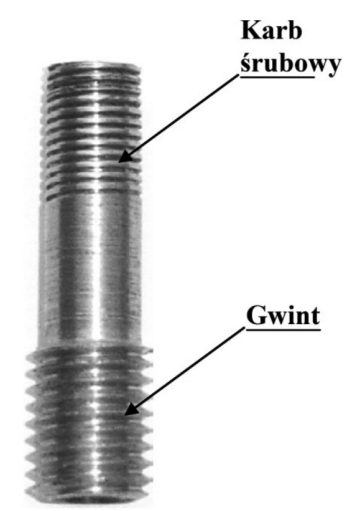

Rys. 2. Próbka implant z karbem śrubowym Fig. 2. Implant specimen with helical notch

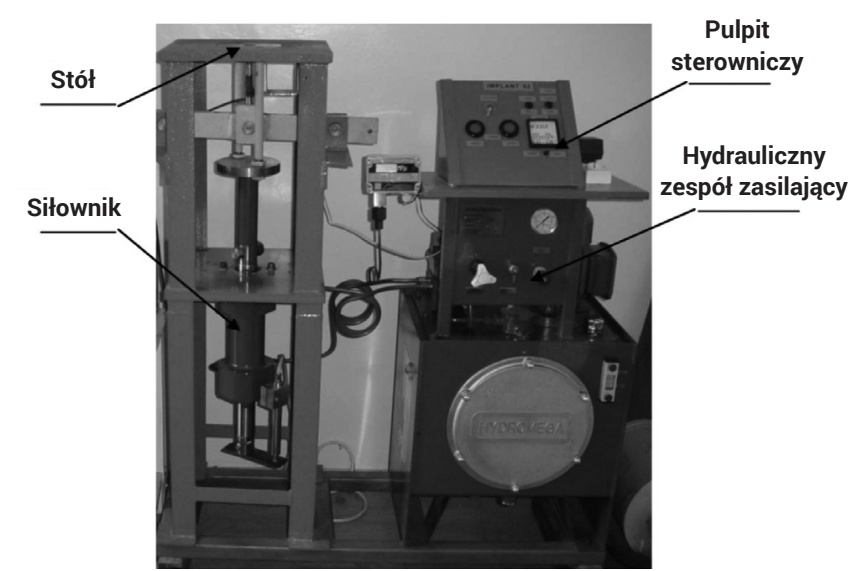

Rys. 3. Stanowisko "Implant 02" [36]

Fig. 3. "Implant 02" test stand 
implant w zakresie naprężeń krytycznych $\sigma_{\mathrm{kr}}=50 \div 400 \mathrm{MPa}$ wynosi $10 \%$.

Próba implant posiada wiele zalet, które decydują o jej wyższości nad innymi metodami. Zaliczyć do nich należy m.in. $[22,26 \div 29]$ : małe rozmiary próbki, możliwość wykonania płyt pomocniczych ze stali o składzie chemicznym różniącym się od materiału implantów, lecz o zbliżonej wartości współczynnika przewodzenia ciepła (z tej samej grupy materiałowej wg TR ISO 15608), możliwość sterowania parametrami kształtującymi cykl cieplny spawania, znajomość rzeczywistych naprężeń panujących w próbce przy jednoczesnym uniezależnieniu ich od technologii spawania, możliwość ilościowego określenia wyników i ich porównania z badaniami przeprowadzonymi innymi metodami oraz powtarzalność pomiarów. Próbki po przeprowadzeniu próby można wykorzystać do dalszych badań, np. metalograficznych i pomiarów twardości. Na rysunku 4 pokazano fotografię zgładu metalograficznego próbki typu implant [21].

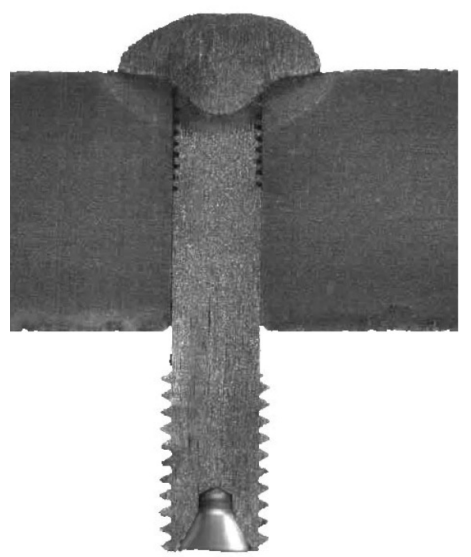

Rys. 4. Zgład metalograficzny próbki implant

Fig. 4. Metallographic cross-section of implant specimen

Do wad próby implant należy zaliczyć przede wszystkim brak ostatecznego powiązania pomiędzy $\sigma_{\mathrm{kr}}$ i naprężeniami w rzeczywistych konstrukcjach spawanych $[31,39,40]$, czasochłonność procedury badawczej oraz wynikającą z natury pękania zimnego mnogość czynników, które należy kontrolować podczas realizacji badań [54].

Przeprowadzenie prób implant umożliwia, poza określeniem skłonności SWC do tworzenia pęknięć zimnych w danych warunkach [37], zbadanie wpływu poszczególnych czynników na ten wskaźnik [38], określenie minimalnej temperatury podgrzewania wstępnego wykluczającej pękanie $[9,41]$ lub wyznaczenie bezpiecznego poziomu wodoru dyfundującego [25]. Może być wykorzystana zarówno do kwalifikowania technologii spawania, jak i do badań naukowych o charakterze podstawowym, np. do określenia mechanizmów pękania [38]. Na rysunku 5 pokazano fotografię przełomu próbki implant, która uległa zniszczeniu. Próbę można zastosować również do badania skłonności do tworzenia pęknięć zimnych w spoinie. W tym wypadku implanty należy wykonać z centralnej części spoin złączy wykonanych np. metodami MMA i SAW $[15,25]$. Próbę z powodzeniem stosowano również do oceny spawalności stali w środowisku wodnym $[21,32,42]$.

Jak wskazują doświadczenia, opisywana metoda umożliwia przeprowadzenie badań na próbkach z praktycznie każdego gatunku stali $[25,34,43,44]$ i dowolną metodą spawania $[35,45]$. Charakterystyczny jest brak w literaturze wyników badań dla próby implant i metody spawania TIG [21], co może wynikać z generowania niskiej ilości wodoru dyfundującego w stopiwie i obszaru zastosowania tej metody (elementy o małej grubości).

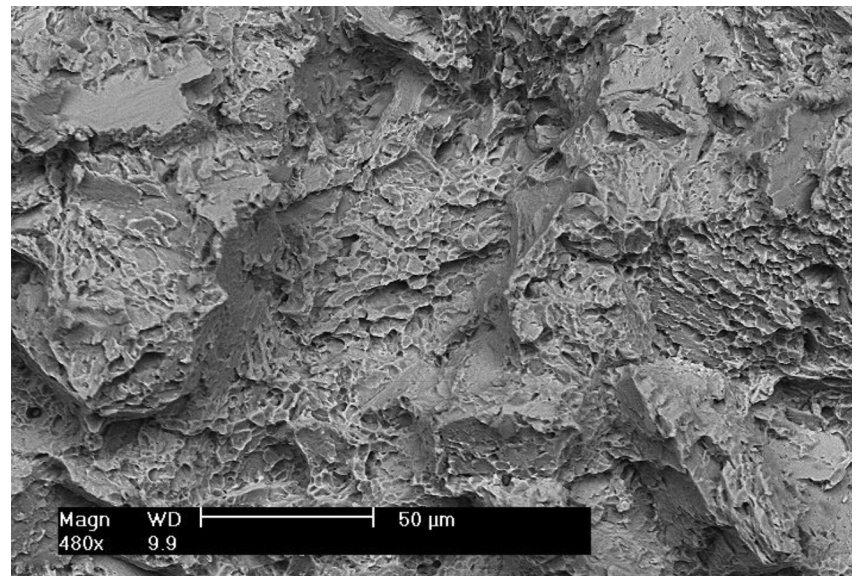

Rys. 5. Fotografia przełomu pęknięcia zimnego. Przełom kruchy transkrystaliczny i częściowo międzykrystaliczny ze śladami odkształcenia plastycznego [21]

Fig. 5. Photography of fracture of cold crack. Transgranular and partly intergranular brittle fracture with traces of plastic deformation

\section{Interpretacja wyników próby implant}

Sposoby przedstawiania (wizualizacji), a zwłaszcza interpretacja wyników próby implant stanowiły przedmiot intensywnych badań od początku jej opracowania [22,24,25,27,30]. Praktyka wykazała, że najwłaściwsze jest przedstawienie wyników poszczególnych prób tworzących serię na wykresie w układzie półlogarytmicznym naprężenia w płaszczyźnie karbu (implantacyjne) $\sigma_{i}-\log t[24,26]$. Na rysunkach $6 \div 8$ przedstawiono trzy warianty graficznej reprezentacji tych samych wyników: w klasycznym układzie: $\sigma_{i}-t$, oraz zalecanych układach: $\sigma_{i}-\log t$ oraz uśrednione $\sigma_{i}-\log t$.

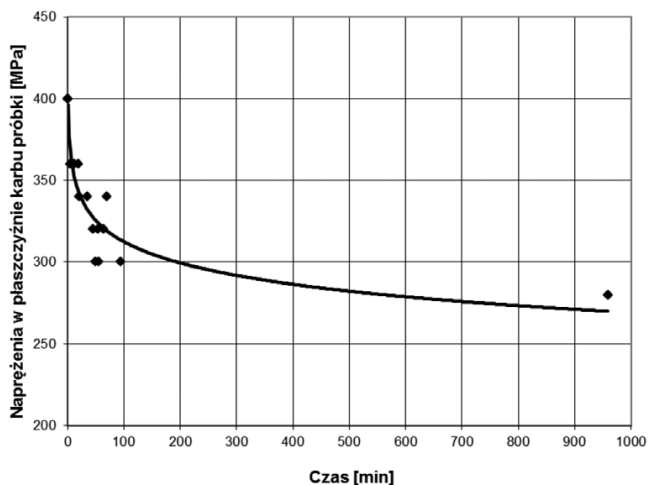

Rys. 6. Wyniki prób implant $\mathrm{w}$ układzie $\sigma_{\mathrm{i}}-\mathrm{t}$ : spawanie pod wodą metodą lokalnej komory suchej, stal S355J2G3, $\mathrm{Wg}=50 \mathrm{l} / \mathrm{min}$, $\mathrm{e}_{\mathrm{L}}=10 \mathrm{~kJ} / \mathrm{cm}[21]$

Fig. 6. Results of implant tests in $\sigma_{i}-t$ system: underwater welding by local cavity, S355J2G3 steel, $\mathrm{Wg}=50 \mathrm{l} / \mathrm{min}, \mathrm{e}_{\mathrm{L}}=10 \mathrm{~kJ} / \mathrm{cm}$

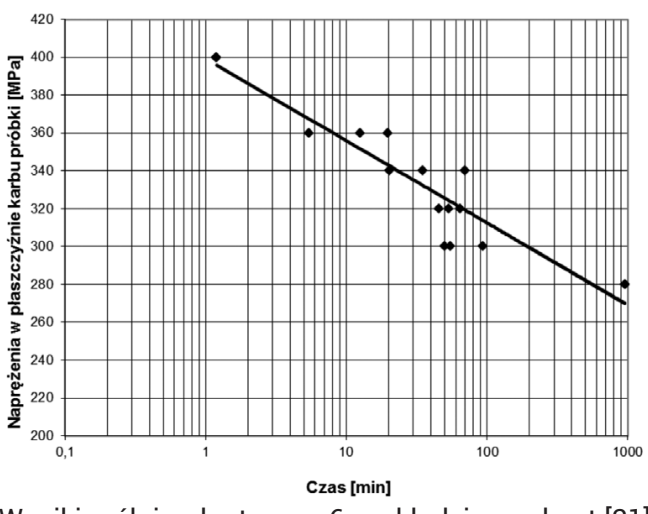

Rys. 7. Wyniki prób implant z rys. $6 \mathrm{w}$ układzie $\sigma_{i}-\log \mathrm{t}$ [21] Fig. 7. Results of implant tests from fig. 6 in $\sigma_{i}-\log t$ system 


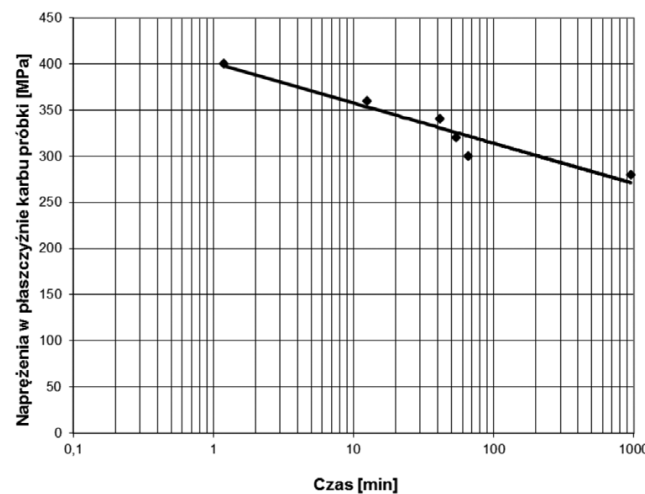

Rys. 8. Wyniki prób implant z rys. 6 w układzie uśrednione $\sigma_{i}-\log \mathrm{t}$ [21] Fig. 8. Results of implant tests from fig. 6 in mean $\sigma_{i}-\log t$ system

Obecnie naprężenia krytyczne $\mathrm{z}$ próby implant $\sigma_{\mathrm{kr}}$ odnosi się do granicy plastyczności badanej stali Re [3] otrzymując bezwymiarowy współczynnik a (zwany również naprężeniami znormalizowanymi):

$$
a=\sigma_{\mathrm{kr}} / \mathrm{Re}
$$

gdzie:

$\sigma_{\mathrm{kr}}$ - naprężenia krytyczne z próby implant [MPa],

Re - granica plastyczności materiału podstawowego (implantu) [MPa].

Naprężenia krytyczne można odnieść do parametru NTS (ang. notched tensile strength) - wytrzymałości na rozciąganie próbki z karbem [6]. Zaproponowano również wyrażanie wyniku jako stosunku naprężeń krytycznych i wytrzymałości na rozciąganie strefy gruboziarnistej SWC (CGHAZ) określonej na podstawie jej twardości [18]. Interpretacja wyników próby implant, wyrażonych w postaci współczynnika a [3], odpowiada trójstopniowej skali skłonności stali do tworzenia pęknięć zimnych. Szczegółowo przedstawiono to $\mathrm{w}$ tablicy I. Stale odporne na powstawanie zimnych pęknięć nie wymagają kontrolowania zawartości wodoru w spoinie i cieplnych warunków spawania. Stale częściowo skłonne do pękania zimnego wymagają kontrolowania zawartości wodoru w spoinie, natomiast stale cechujące się skłonnością do pękania zimnego wymagają kontrolowania zarówno zawartości wodoru w spoinie, jak i cieplnych warunków spawania [3].

\section{Określanie skłonności stali do tworzenia pęknięć zimnych wg naprężeń krytycznych}

Na podstawie wyników prób implant opracowano analityczną metodę oceny spawalności stali o podwyższonej wytrzymałości [3]:

$\sigma_{\mathrm{kr}}=9,81 \times\left(68,9-121 \times \mathrm{P}_{\mathrm{cm}}-24 \times \log \left(\mathrm{H}_{\mathrm{D}}+1\right)+\right.$

gdzie:

$$
\mathrm{P}_{\mathrm{cm}}=C+\frac{S i}{30}+\frac{M n+C r+C u}{20}+\frac{N i}{60}+\frac{M o}{15}+\frac{V}{10}+5 B
$$

$$
\mathrm{t}_{8 / 5}=\left(6700-5 \cdot t_{0}\right) \cdot k \cdot f \cdot e_{L}\left(\frac{1}{500-t_{0}}-\frac{1}{800-t_{0}}\right)
$$

gdzie:

$\mathrm{H}_{\mathrm{D}}$ - zawartość wodoru dyfundującego w stopiwie

[ml/100g stopiwa],

$\mathrm{t}_{8 / 5}$ - czas stygnięcia w zakresie temperatur $800 \div 500{ }^{\circ} \mathrm{C}$ [s],

$\mathrm{t}_{100}$ - czas stygnięcia do temperatury $100^{\circ} \mathrm{C}[\mathrm{s}]$,

k - współczynnik względnej sprawności procesu spawania [-],

f - współczynnik kształtu złącza [-],

$\mathrm{t}_{0}$ - temperatura początkowa spawanego elementu $\left[{ }^{\circ} \mathrm{C}\right]$,

$\mathrm{e}_{\mathrm{L}}$ - energia liniowa spawania $[\mathrm{kJ} / \mathrm{mm}$.

Zależność ta obowiązuje dla następujących zakresów wartości zmiennych istotnych:

$P_{c m}=0,16 \div 0,282[\%]$,

$\mathrm{H}_{\mathrm{D}}=1 \div 21[\mathrm{ml} / 100 \mathrm{~g}]$

$\mathrm{t}_{8 / 5}=5 \div 20[\mathrm{~s}]$,

$\mathrm{t}_{100}=58,5 \div 1409[\mathrm{~s}]$.

Jest to jedyna zależność umożliwiająca ocenę stopnia skłonności stali do tworzenia pęknięć zimnych, która uwzględnia warunki cieplne procesu spawania [3].

\section{Zastosowanie analiz wielowymiarowych do oceny spawalności stali metodą implant}

Biorąc pod uwagę zasadę i warunki przeprowadzania prób implantacyjnych $[12,37]$ przy wykorzystaniu teorii planowania badań można otrzymać dwa rodzaje zależności. Pierwsza posiada postać ogólną [21]:

gdzie:

$$
\sigma_{k r}=f\left(x_{1}, x_{2}, \ldots x_{n}\right) \text {, }
$$

$\sigma_{\mathrm{kr}}$ - naprężenie krytyczne z próby implant [MPa],

$\mathrm{x}_{1}, \mathrm{x}_{2}, \ldots \mathrm{x}_{\mathrm{n}}$ - czynniki wejściowe.

Ten typ zależności charakteryzuje się tym, że za kryterium odporności na powstawanie pęknięć zimnych przyjąć można bezwymiarową zależność zalecaną w literaturze [3]:

$$
\alpha=\frac{\sigma_{k r}}{\operatorname{Re}}
$$

Ze względu na to, że naprężenie krytyczne z próby implant $\sigma_{\mathrm{kr}}$ odnosi się do granicy plastyczności Re, która jest wartością stałą dla danego materiału, można również posłużyć się następującym wariantem powyższej zależności [21]:

gdzie:

$$
a=f\left(x_{1}, x_{2}, \ldots x_{n}\right)
$$

$\mathrm{x}_{1}, \mathrm{x}_{2}, \ldots \mathrm{x}_{\mathrm{n}}$ - czynniki wejściowe.

Natomiast druga z proponowanych zależności przyjmuje postać [21]:

gdzie:

$$
t_{z}=f\left(\sigma_{i}, x_{2}, \ldots x_{n}\right),
$$

$\mathrm{t}_{\mathrm{z}}$ - czas do zerwania próbki (implantu) [h],

$\sigma_{i}$ - naprężenia w płaszczyźnie karbu kołka (implantacyjne) [MPa],

$\mathrm{x}_{1}, \mathrm{x}_{2}, \ldots \mathrm{x}_{\mathrm{n}}-$ czynniki wejściowe.

Tablica I. Ocena skłonności stali do tworzenia pęknięć zimnych na podstawie wskaźnika a [3] Table I. Assessment of steel susceptibility to cold cracking on the basis of a coefficient

\begin{tabular}{|c|c|}
\hline Wartość współczynnika a [-] & Klasa wrażliwości na tworzenie pęknięć zimnych \\
\hline$a>1$ & stal odporna na tworzenie pęknięć zimnych \\
\hline $0,6<a<1$ & stal częściowo skłonna do tworzenia zimnych \\
\hline$a<0,6$ & stal skłonna do tworzenia pęknięć zimnych \\
\hline
\end{tabular}


W tym przypadku za kryterium skłonności do powstawania pęknięć należy przyjąć czas krytyczny $-t_{k}$, po którego przekroczeniu pęknięcia zimne nie występują [21]. W sytuacji, gdy czas do zerwania próbki $t_{z}$ jest dłuższy od przyjętego czasu krytycznego $t_{k}$, stal jest odporna na tworzenie pęknięć zimnych, natomiast w przypadku przeciwnym stal uznać należy za skłonną do tworzenia pęknięć zimnych.

Wyniki badań metodą implant można również przedstawić w postaci wartości dychotomicznych (dwustanowych) przyjmując, np. wszystkie wyniki prób zakończonych zerwaniem próbki jako 1, a wyniki prób trwających dłużej niż przyjęty czas krytyczny (najczęściej 16 h) jako 0 [46]. Takie podejście

$$
f(x)=\frac{e^{x}}{1+e^{x}}
$$

umożliwia wykorzystanie regresji logistycznej i opracowanie zależności o następującej postaci ogólnej [47]:

Równanie to posiada relatywnie prostą interpretację graficzną (krzywą sigmoidalną) i można na jego podstawie obliczyć prawdopodobieństwo pęknięcia dla wybranych wartości czynników badanych [48]. Zakodowanie wyników badań do postaci dychotomicznej umożliwia również zastosowanie analizy przeżycia (niezawodności) [47].

\section{Podsumowanie}

Próba implant została opracowana około 50 lat temu i zyskała akceptację na całym świecie. Otrzymane podczas jej realizacji wyniki badań stanowiły podstawę do oceny spawalności nowych, wprowadzanych do powszechnego zastosowania, gatunków stali o podwyższonej i wysokiej wytrzymałości oraz poznania mechanizmów odpowiedzialnych za formowanie się pęknięć zimnych [5,12,17,18,21,31,36,49].

Metoda należy do zaawansowanych prób technologicznych umożliwiających ocenę spawalności stali w porównaniu do prób utwierdzonych. Charakteryzuje się dużą czasochłonnością oraz koniecznością dokładnego i powtarzalnego wykonania próbek typu implant. Jednocześnie wymaga stosowania się do określonej metodyki wykonywania badań. Należy jednak podkreślić, że korzyści wynikające z jej zastosowania rekompensują poniesione wysiłki, np. możliwe jest przy zastosowaniu analiz statystycznych otrzymanych wyników tworzenie zależności empirycznych przeznaczonych do oceny skłonności badanych stali do pękania zimnego.

\section{Literatura}

[1] Łomozik M.: Metaloznawstwo i spawalność metali. Materiały szkoleniowe Instytutu Spawalnictwa, Gliwice 1997

[2] Tasak E.: Spawalność stali. Wydawnictwo Fotobit, Kraków 2002

[3] Mikuła J., Wojnar L.: Analityczne metody oceny spawalności stali. Wydawnictwo Fotobit, Kraków 1996.

[4] Kozak T.: Pękanie opóźnione złączy spawanych. Przegląd Spawalnictwa 8-10/2002.

[5] Kozak T.: Resistance to cold cracking of welded joints made of P460NL1 steel. Advances in Materials Sciences 3/2011.

[6] Vuik J.: An update of the state-of-the-art of weld metal hydrogen cracking. Welding in the World $5 / 1993$

[7] Kannengiesser T., Boellinghaus T.: Cold cracking tests-an overview of present technologies and applications. Welding in the World 1/2013.

[8] Brózda J., Zeman M.: Sposoby oceny spawalności stali stosowane w Instytucie Spawalnictwa. Biuletyn Instytutu Spawalnictwa 5/1995

[9] Suzuki H., Terasaki T.: Estimating critical stress and preheat temperature to avoid cold cracking in implant and JIS-y (Tekken) test. IIW Doc. IX-1417-86.

[10] PN-EN ISO 17642-1:2005 Badania niszczące spoin w metalach. Badania pękania na zimno złączy spawanych. Metody spawania łukowego. Część 1: Postanowienia ogólne.

[11] Zeman M.: Zastosowanie symulatora cykli cieplno-odkształceniowych do badania skłonności stali do pękania zimnego. Biuletyn Instytutu Spawalnictwa 6/1993.

[12] Neuman V., Florian W., Schonherr W.: The hydrogen influenced cold cracking tendency of low alloyed high strength steels-evaluated by the implant test. IIW Doc. IX-1224-82.

[13] Fang C.K., Kannatey E., Barber J.R.: Acoustic emission investigation of cold cracking in Gas Metal Arc Welding of AISI 4340 steel. Welding Journal 6/1995.

[14] Pilarczyk J.: Wykorzystanie emisji akustycznej do wykrywania pęknięć powstających w złączach w procesie spawania. Przegląd Spawalnictwa 6/1977.

[15] Savage W. F., Nippes E.F., Sawhill J.M.: Hydrogen induced cracking during implant testing of alloy steels. Welding Journal 12/1976.

[16] Grębski S.: Badanie pękania zimnego stali z wykorzystaniem emisji akustycznej. Praca dyplomowa inżynierska zrealizowana pod kierunkiem dr. inż. Dariusza Fydrycha. Politechnika Gdańska 2016

[17] Mikuła J.: Morfologia przełomów pęknięć zimnych. Przegląd Spawalnictwa 5/1987.

[18] Yue X., Lippold J.C.: Evaluation of heat-affected zone hydrogen induced cracking in Navy steels. Welding Journal 1/2013.

[19] Fydrych D., Łabanowski J., Tomków J., Rogalski G.: Cold cracking of underwater wet welded S355G10+ N high strength steel. Advances in Materials Science 3/2015.

[20] Fydrych D., Łabanowski J., Rogalski G., Haras J., Tomków J., Świerczyńska A., Jakóbczak P., Kostro.$:$ Weldability of S500MC steel in underwater conditions. Advances in Materials Science 2/2014.

[21] Fydrych D.: Wpływ warunków spawania na skłonność do tworzenia pęknięć zimnych przy spawaniu pod wodą. Praca doktorska, Politechnika Gdańska, Gdańsk 2005.

[22] Granjon H.: The "implants" method for studying the weldability of high strength steels. Metal Construction and British Welding Journal 11/1969.

[23] Tan Ch., Ge X., Lin Q., Florian W., Noack V.: The investigation of implant cold cracking test. IIW Doc. IX-1729-94.

[24] Development and use of the implant test. „Welding Journal” 7/1972.

[25] Hart P.H.M., Watkinson E.: Weld metal implant test ranks Cr-Mo hydrogen cracking resistance. Welding Journal 9/1975.

[26] Mazur M., Adamiec P., Dziubiński J., Dudek P.: Zastosowanie próby kołkowej (implantacyjnej) do badania pęknięć zimnych. Przegląd Spawalnictwa 11-12/1973.
[27] Sawhill J. M., Dix A. W., Savage W. F.: Modified implant test for studying delayed cracking. Welding Journal 12/1974.

[28] Aavatsmark N.E., Evans G.M.: Correlation of the cruciform test with the implant test. IIW Doc. IX-810-72.

[29] Satoh K. i in.: Correlation of the implant test with the RRC and TRC tests. IIW Doc. IX-874-74.

[30] Karppi R., Ruusila J., Satoh K., Toyoda M., Vartiainen K.: Note on standardization of implant test. Technical Research Centre of Finland 1983.

[31] Pilarczyk J.: Wykorzystanie próby kołkowej w badaniach spawalności stali. Prace Instytutu Spawalnictwa 4/1978.

[32] Bohme D., Eisenbeis C.: Investigation into the credibility of the implant test when used to assess the cold cracking sensitivity of underwater wet welds. Proceedings of the International Conference "Welding Under Extreme Conditions", Helsinki, Finland 1989.

[33] Savage W.F., Nippes E.F., Szekeres E.S.: Hydrogen induced cold cracking in a low alloy steel. Welding Journal 9/1976

[34] Savage W.F., Nippes E.F., Pellman M.A.: Hydrogen-induced cracking in soviet steels involved in USA/USSR exchange program. Welding Journal 11/1979.

[35] Tan Ch., Zhou Z., Cai H.: Availability of implant test for assessing hydrogen induced cracking in submerged arc weldment. IIW Doc. IX-1490-87.

[36] Kozak T.: Zachowanie się złączy spawanych w czasie spawania i eksploatacji. Sprawozdanie DS 014667, Politechnika Gdańska, Gdańsk 2001.

[37] PN-EN ISO 17642-3:2005 Badania niszczące spoin w metalach. Badania pękania na zimno złączy spawanych. Metody spawania łukowego. Część 3: Badania z obciążeniem zewnętrznym.

[38] Cold cracking tests. IIW Doc. II-1513-03

[39] Ranatowski E.: Elementy fizyki spajania metali. Wydawnictwa Uczelniane Akademii Techniczno-Rolniczej, Bydgoszcz 1999.

[40] Стеренбоген Ю.А., Васильев Д.В.: Новая методика и энергетические критерии оценки стойкости металла ЗТВ сварного соединения против образования холодных трещин. Автоматическая Сварка 6/1997.

[41] Florian W., Akin E.: Comparison of necessary preheat temperature to avoid cold cracking in HAZ. IIW Doc. IX-1939-99.

[42] Garašić I., Kralj S., Kožuh Z.: Investigation into cold cracking in underwater wet weIding of API 5 L X70 steel. Transactions of FAMENA 3/2009.

[43] Миходуй Л.И., Позняков В.Д., Ющенко А.К.: Сопротивлаемость замедленному разрушению сварных соединений стали 12ХГН2МФДРА. Автоматическая Сварка 11/2000.

[44] Швачко В.И., Степанюк С.Н.: Особенности холодного растрескивания при сварке высокопрочных низколегированых сталей. Автоматическая Сварка $5 / 2002$.

[45] Gedeon S.A., Eagar T.W.: Assessing hydrogen-assisted cracking fracture modes in high-strength steel weldments. Welding Journal 6/1990.

[46] Koszorek M.: Spawalność stali o podwyższonej wytrzymałości pod wodą. Praca dyplomowa magisterska zrealizowana pod kierunkiem dr. inż. Dariusza Fydrycha. Politechnika Gdańska 2015.

[47] Stanisz A.: Przystępny kurs statystyki: z zastosowaniem STATISTICA PL na przykładach z medycyny. Analizy wielowymiarowe. StatSoft, Kraków 2007.

[48] Larose D.T.: Metody i modele eksploracji danych. Wydawnictwo Naukowe PWN, Warszawa 2008.

[49] Pańcikiewicz K., Zielińska-Lipiec A., Tuz. L., Rakoczy Ł.: Ocena skłonności do pęknięć zimnych złączy spawanych stali w próbie implantacyjnej. Przegląd Spawalnictwa 4/2016. 